Diabetologia 11, 21-25 (1975)

(c) by Springer-Verlag 1975

\title{
Synthesis of Proinsulin and Large Glucagon Immunoreactivity in Isolated Langerhans Islets from EMC-Virus Infected Mice*
}

\author{
K.-G. Petersen, P. Heilmeyer and L. Kerp \\ Abteilung für klinische Endokrinologie der Medizin.-Univ.-Klinik, Freiburg i. Br., Federal Republic of Germany
}

Received: January 28, 1974, and in revised form: August 1, 1974

\begin{abstract}
Summary. The protein synthesis in normal and in EMCvirus infected mouse islets of Langerhans was investigated. Mouse large glucagon immunoreactivity was determined by an immunoassay after chromatographic separation. It was characterized as a peptide of $16000 \mathrm{MW}$ with in intracellular half-life of 35-45 min. The proportional reduction of void volume proteins, large glucagon immunoreactivity and proinsulin synthesis after infection shows, that both alphaand beta-cells are damaged by the virus. A reduction in the synthesis of the three protein fractions was already found
\end{abstract}

$6 \mathrm{hrs}$ after inoculation of the virus and remained nearly constant for $48 \mathrm{hrs}$. An almost complete breakdown of protein synthesis occured 60 to $70 \mathrm{hrs}$ after infection and was paralleled by the first light microscopic changes in the islets. The stimulation of proinsulin synthesis by glucose was preserved for $48 \mathrm{hrs}$ after EMC-virus infection.

Key-words: EMC-virus infection, virus infection and protein-synthesis in the islets of Langerhans, proinsulin-synthesis, large glucagon immunoreactivity.
A diabetes mellitus-like disease develops in mice infected with the M-variant of the encephalomyocarditis (EMC) virus $[2,3,6]$.

Hyperglycemia and glucosuria appear in infected animals approximately five days after the inoculation of EMC-virus. Low levels of plasma and pancreatic insulin are found during the acute stages of the infection. Large amounts of virus are recovered from the pancreas. Some animals exhibit chronic impairment of carbohydrate metabolism, while others eventually recover normal glucose tolerance.

Three days after the inoculation of EMC-virus in mice beta-cell necrosis was observed, five days after infection round cell infiltration of the islets of Langerhans appeared [7]. This study presents experimental data on the synthesis of proinsulin (PI) and large glucagon immunoreactivity (LGI) in isolated islets of Langerhans from EMC-virus infected mice.

\section{Materials and Methods}

A virus pool was prepared by homogenizing the hearts from male NMRI mice $(21-23 \mathrm{~g}) 48 \mathrm{hrs}$ after the inoculation of the M-variant of the encephalomyocarditis (EMC) virus. The final pool contained one heart in $10 \mathrm{ml}$ Krebs-Ringer bicarbonate buffer. Aliquots were stored at $-30^{\circ} \mathrm{C} .1 \mathrm{ml}$ of this viruspool contained $10^{5}-10^{6}$ mice infective doses $\left(\mathrm{MID}_{50}\right)$

\footnotetext{
* Parts of the results were presented at the meeting of the "Deutsche Diabetes Gesellschaft" Munich, June 1973.
}

determined by weight controls. Male NMRI mice $(30-38 \mathrm{~g})$ were inoculated by subcutaneous injections of $0.2 \mathrm{ml}$ of the virus-pool. Glucose tolerance tests performed in the infected mice, remained unchanged during the first three days, corresponding to earlier findings [7].

The third day after infection the islets of Langerhans were microdissected in phosphate Ringer buffer at $4^{\circ} \mathrm{C}$ [5]. In the course of $60 \mathrm{~min}$ about 30 islets were collected and transferred to a perifusion chamber according to [9]. Perifusion was performed with Krebs-Ringer bicarbonate buffer at $37^{\circ} \mathrm{C}$ with a gas

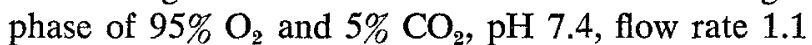
$\mathrm{ml} / \mathrm{hr}$. Labelling was done with a ${ }^{3} \mathrm{H}-\mathrm{L}$-amino acid mixture from NEN (NET 250; the amino acid composition is available from NEN Chemicals). The specific activity of the amino acid mixture was $5-15$ $\mathrm{mCi} / \mathrm{mmole}$, the final concentration in the incubation medium was $0.07 \mathrm{mCi} / \mathrm{ml}$. In a further series of experiments ${ }^{3} \mathrm{H}-\mathrm{L}-\mathrm{leucine}$ was used (specific activity 50 $\mathrm{Ci} / \mathrm{mmole}$, NET $135 \mathrm{H}$ from NEN) in a final concentration in the incubation medium of $0.03 \mathrm{mCi} / \mathrm{ml}$. Unlabelled amino acids were added corresponding to low serum levels in mice (in $\mu$ mole/l):

$\begin{array}{lrrrrr}\text { Asp } & 1.8 ; & \text { Gly } & 63.0 ; & \text { Leu } & - \text {; } \\ \text { Tyr } & 15.0 ; & \text { Ser } & 28.5 ; & \text { Val } & 81.5 ; \\ \text { Cys } & 9.0 ; & \text { Pro } & 65.0 ; & \text { Met } & 9.0 ; \\ \text { Ile } & 11.5 ; & \text { His } & 25.5 ; & \text { Arg } & 23.0 ; \\ & \text { Thre } & 20.0 ; & \text { Ala } & 58.5 ; & \\ & \text { Phe } & 12.0 ; & \text { Glu } & 31.0 ; & \\ & \text { Lys } & 71.5 ; & \text { Cit } & 14.0 ; & \end{array}$


The glucose concentrations used were 1.0 and 3.0 $\mathrm{mg} / \mathrm{ml}$. Perifusion was chosen to avoid any effect of accumulating glucagon or insulin on protein synthesis in isolated islets. Perifusates were analysed and did not contain measurable amounts of ${ }^{3} \mathrm{H}-\mathrm{PI}$ or ${ }^{3} \mathrm{H}-$ LGI. Incorporation of amino acids into proteins was measured after a perifusion period of $60 \mathrm{~min}$. During this time practically no tritiated insulin is formed. Addition of cycloheximide $(100 \mu \mathrm{g} / \mathrm{ml})$ caused a more than $95 \%$ inhibition of protein synthesis. Incubation was stopped by transferring the islets to $3 \mathrm{M}$ acetic acid with $0.25 \%$ albumin. The islets were destroyed by sonication. The proinsulin content of islets from male NMRI mice, determined by a cellulose adsorption method [4], was $130 \pm 30 \mu \mathrm{U} /$ islet $(\mathrm{n}=20$; mouse insulin standard) showing good reproducibility of the extraction procedure. The use of an acid ethanol extraction was of no advantage.

Labelled proteins were separated on a Biogel $\mathrm{P}$ 60 column $(12 \times 500 \mathrm{~mm})$ with $3 \mathrm{M}$ acetic acid, containing $0.25 \%$ albumin (flow $2.7 \mathrm{ml} / \mathrm{h}$ ). Fractions of $0.94 \mathrm{ml}$ were collected and freeze dried. Biogel P 10 and P 60 were compared. Only Biogel P 60 yielded a satisfying separation of LGI and void volume fractions. Calibration was done with blue dextran (fraction 11-13), cytochrome $\mathrm{C}$ (fraction 23-25), porcine proinsulin (fraction $38-41$ ), mouse insulin (fraction 43-47) and amino acids (fraction 47-52). Control experiments with exogenous ${ }^{131}$ I-bovine insulin, bovine proinsulin and porcine glucagon revealed a recovery of 93 to $95 \%$.

\section{Proinsulin (PI)}

PI was labelled with ${ }^{3} \mathrm{H}-\mathrm{L}-$-leucine or the ${ }^{3} \mathrm{H}-\mathrm{L}$ amino acid mixture and determined after chromatography. Samples were incubated for $5 \mathrm{hrs}$ with and without cross reacting anti-bovine insulin serum (2\%) from guinea pigs in $2 \mathrm{ml} 0.2 \mathrm{M}$ Tris-buffer containing $0.25 \%$ serum albumin, $\mathrm{pH} 8.2$. For the adsorption of free proinsulin $100 \mathrm{mg}$ of cellulose MN 100 (Macherey and Nagel, Düren) were added to each sample. Antibody bound ${ }^{3} \mathrm{H}-\mathrm{PI}$ could be calculated from the radioactivity in the supernatants of both samples.

\section{Large Glucagon Immunoreactivity (LGI)}

LGI has been described for different species [10]. A chromatographically corresponding protein in mice islets was labelled by perifusion of the isolated islets with the ${ }^{3} \mathrm{H}-\mathrm{L}$-amino acid mixture and separated by gelfiltration. This protein could be identified by its specific binding to isolated $\gamma$-globulins of pooled antiporcine glucagon sera from rabbits. The antiserum concentration was $2 \%$ in $2 \mathrm{ml} 0.2 \mathrm{M}$ Tris-buffer containing $0.25 \%$ serum albumin and $500 \mathrm{KIE}$ Trasylol $\mathrm{R} / \mathrm{ml}$. Samples were incubated for $12 \mathrm{hrs.}{ }^{3} \mathrm{H}-\mathrm{L}$ GI antibody complexes were separated from free ${ }^{3} \mathrm{H}-\mathrm{LGI}$ by preparative ultracentrifugation $(100,000 \mathrm{~g}, 360$ min, $4^{\circ} \mathrm{C}$ ). The antibody binding of ${ }^{3} \mathrm{H}$-labelled LGI from mice islets could be completely inhibited by porcine glucagon in excess.

The anti-bovine insulin serum from guinea pigs used for the proinsulin immunoassay showed no crossreaction with mouse LGI; the anti-porcine glucagon serum from rabbits did not crossreact with mouse proinsulin. This was checked by ultracentrifugation ob both diluted antisera in the presence of ${ }^{8} \mathrm{H}-\mathrm{LGI}$ and ${ }^{3} \mathrm{H}-\mathrm{PI}$. ${ }^{3} \mathrm{H}-\mathrm{PI}$ and ${ }^{3} \mathrm{H}-\mathrm{LGI}$ from mice were quantitatively displaced from the antibody binding by addition of excess mouse insulin or porcine glucagon.

Trypsination of ${ }^{3} \mathrm{H}-\mathrm{PI}$ and ${ }^{3} \mathrm{H}-\mathrm{LGI}$ was carried out in $0.02 \mathrm{M}$ Tris-buffer with $0.25 \%$ albumin, $\mathrm{pH} 7.4$ and $0.001 \mu \mathrm{g} / \mathrm{ml}$ trypsin at $37^{\circ} \mathrm{C}$ for $30 \mathrm{~min}$.

\section{Results}

After perifusion of islets of Langerhans from normal mice, gelfiltration showed that labelled void volume proteins were followed by a first peak containing large glucagon immunoreactivity (LGI) and a second peak with proinsulin (PI). The molecular weight of LGI was $16,000 \pm 1000$. Trypsination of PI yielded a smaller peptide eluting with mouse insulin, whereas after trypsination of LGI smaller peptides than porcine glucagon were obtained in agreement with earlier results [8]. Hydrolysis of ${ }^{3} \mathrm{H}-$ LGI by boiling in $6 \mathrm{~N} \mathrm{HCL}$ followed by amino acid analysis on Chromo Beads type $\mathrm{B}$ revealed that ${ }^{3} \mathrm{H}$ radioactivity could be quantitatively recovered in amino acids. Relatively high amounts of asparagine, tyrosine and arginine were found. For the determination of half lives of LGI and PI, $100 \mu \mathrm{g} / \mathrm{ml}$ cycloheximide was added to the incubation medium after a labelling period of $60 \mathrm{~min}$. Islet proteins were analysed after further incubations of 15,30 and $45 \mathrm{~min}$ following the inhibition of protein synthesis. The intracellular half life of LGI was 35 to 45 min being shorter than that of PI (60 min). By increasing the glucose concentration in the perifusion medium from 1.0 to $3.0 \mathrm{mg} / \mathrm{ml}$ stimulation of proinsulin synthesis occurred. The synthesis of LGI varied by less than $15 \%$ with 1.0 and $3.0 \mathrm{mg}$ glucose/ml perifusion medium (Fig. 1, left chromatogram) whereas the synthesis of void volume proteins increased by $36 \%$.

The gelfiltration of islets obtained $35 \mathrm{hrs}$ after infection of the mice with EMC-virus showed a marked 
reduction of the incorporation of amino acids into void volume proteins, large glucagon immunoreactivity and proinsulin (Fig. 1, right chromatogram). 35 hrs after infection at a concentration of $3.0 \mathrm{mg}$ glu- thesis by glucose is preserved in EMC-virus infected islets of Langerhans. At $1.0 \mathrm{mg}$ glucose $/ \mathrm{ml}$ in the perifusion medium the inhibition of the synthesis, of void volume proteins and large glucagon immuno-
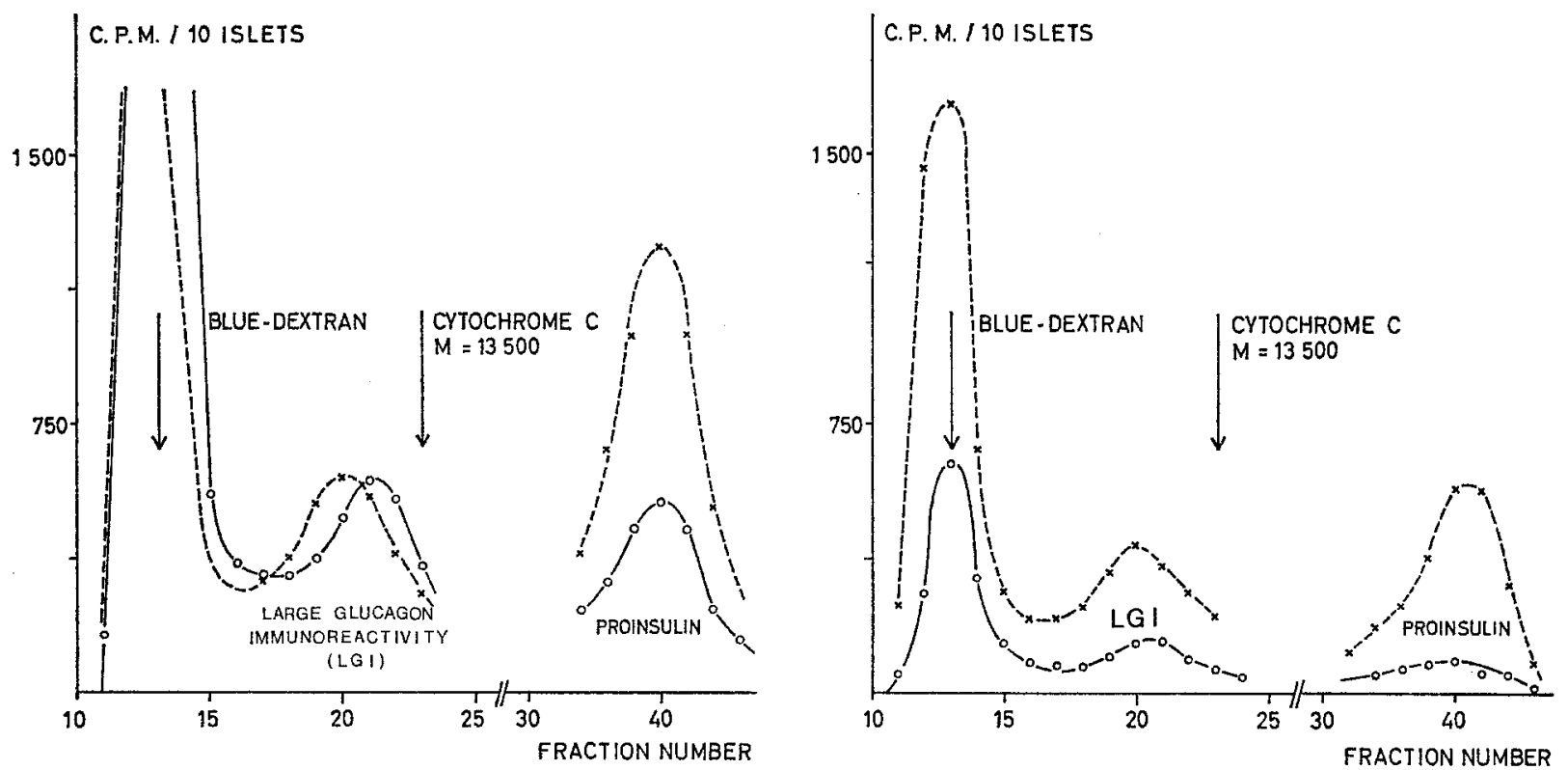

Fig. 1. Eluates from a Biogel P 60 column. Incubation of 30 Langerhans islets for 60 min with ${ }^{3} \mathrm{H}-\mathrm{L}$-amino acid mixture at glucose concentrations of $1.0 \mathrm{mg} / \mathrm{ml} \mathrm{o-o-o}$, and $3.0 \mathrm{mg} / \mathrm{ml} \mathrm{x}-\mathrm{X}-\mathrm{x}$ in the medium. Left chromatogram: Islets from healthy mice; right chromatogram: Islets from EMC-virus infected mice (single results). For calibration data see methods

Table 1. Protein synthesis in islets of Langerhans prepared from mice 6-8 hrs afier infection with EMC-virus. The amino acid incorporation into each fraction of the eluate at $3.0 \mathrm{mg}$ glucose/ $\mathrm{ml}$ is expressed in \% of controls

\begin{tabular}{|c|c|c|c|c|c|}
\hline & & label & proinsulin & $\begin{array}{l}\text { large glucagon } \\
\text { immuno- } \\
\text { reactivity }\end{array}$ & $\begin{array}{l}\text { void volume } \\
\text { proteins }\end{array}$ \\
\hline \multirow{3}{*}{ I } & \multirow{3}{*}{$\begin{array}{l}\text { controls } \\
\mathrm{n}=6 \\
\text { EMC infection } \\
\mathrm{n}=6\end{array}$} & \multirow{3}{*}{${ }^{3} \mathrm{H}-\mathrm{L}-\mathrm{leucine}$} & \multirow{2}{*}{$\begin{array}{l}100 \pm 15.0 \% \%^{\mathrm{a}} \\
2 \mathrm{p}<0.001\end{array}$} & \multirow[t]{2}{*}{-} & $100 \pm 10.3 \%$ \\
\hline & & & & & $2 p<0.001$ \\
\hline & & & $39.9 \pm 13.0 \%$ & - & $37.8 \pm 3.2 \%$ \\
\hline \multirow{3}{*}{ II } & \multirow{3}{*}{$\begin{array}{l}\text { controls } \\
\mathrm{n}=6 \\
\text { EMC infection } \\
\mathrm{n}=5\end{array}$} & \multirow{3}{*}{$\begin{array}{l}{ }^{3} \mathrm{H}-\mathrm{L} \text {-amino } \\
\text { acid mixture }\end{array}$} & $100 \pm 13.6 \%$ & $100 \pm 24.6 \%$ & $100 \pm 18.5 \%$ \\
\hline & & & $2 p<0.001$ & $2 p<0.005$ & $2 p<0.001$ \\
\hline & & & $49.3 \pm 17.0 \%$ & $44.6 \pm 18.9 \%$ & $41.6 \pm 18.7 \%$ \\
\hline
\end{tabular}

I NMRI-mice, 38 days old, $30 \pm 0.7 \mathrm{~g}$ body weight,

II NMRI-mice, 52 days old, $35 \pm 0.9$ g body weight,

a \pm standard error of the mean

cose $/ \mathrm{ml}$ in the medium the synthesis of void volume proteins, large glucagon immunoreactivity and proinsulin in islets from virus infected mice was reduced to about $43 \%$ of the control experiments. The proportional reduction of radioactivity in these fractions shows, that the relative stimulation of proinsulin syn- reactivity was reduced to about $33 \%$, while the synthesis of proinsulin was reduced to $15 \%$ (Fig. 1, right chromatogram).

The results of two series of experiments at $3 \mathrm{mg}$ glucose/ml using islets prepared from male mice $6-8$ hrs after infection with EMC-virus are given in Table 1. 
The reduced level of protein synthesis reached at $6 \mathrm{hrs}$ after infection (Table 1) is maintained for 48 hrs. Then a second phase with a rapid fall of protein synthesis follows. $60-70 \mathrm{hrs}$ after infection the proinsulin synthesis is reduced to about $10-15 \%$ of control values. At this time necrosis of the beta-cells (according to [7]) was observed.

The inhibition of cellular amino acid uptake into void volume proteins, large glucagon immunoreactivity and proinsulin is uniform during the course of virus infection, suggesting a viral damage of both, alpha- and beta-cells. No differences in the relative amino acid uptake into void volume proteins and proinsulin were found using either ${ }^{3} \mathrm{H}-\mathrm{L}$-leucine or a ${ }^{3} \mathrm{H}$-L-amino acid mixture as a marker. A tenfold variation of the injected dose of EMC virus did not alter the results, however prolonged storage of the virus pool reduced the effect on protein synthesis in mice islets. Injection of comparable amounts of polio vaccine virus type II, a picorna virus not infective for mice, was without effect on protein synthesis in the islets of Langerhans. Healthy mice could be infected by isolated islets prepared from infected animals $48 \mathrm{hrs}$ after infection. This proves the presence of virus in the islets, but no data on the degree of infection of alpha- and beta-cells are available. About three days after infection the islets became vitreous and vulnerable. Their recognition in the now whitecoloured exocrine pancreas was increasingly difficult. Since it could not be excluded that after the third day relatively undamaged islets were isolated by the preparative procedure no studies were performed after the third day.

\section{Discussion}

Mouse large glucagon immunoreactivity (LGI) is a peptide of $16,000 \mathrm{MW}$ which is synthesised by the islets of Langerhans and is not secreted. It undergoes intracellular proteolysis with a half life of 35 to 45 $\mathrm{min}$. These findings suggest, according to [8], that LGI is a glucagon precursor. Similar to the findings of these authors [8] trypsination did not yield glucagon. This may be explained by the fact that glucagon has amino acid sequences cleaved by trypsin. The experimental data suggest that the diabetes syndrome in EMC-virus infected mice, observed five days after infection, is caused by a direct action of the virus on the islets of Langerhans. The early reduction of protein synthesis observed in islets from infected mice is typical of cellular infection with picorna viruses [1, 11]. The early measurable reduction of protein synthesis 6 hrs after infection, using low mice infective doses of the EMC virus pool, may be explained by the possibility that one mouse infective dose may contain a much higher virus concentration than one infective particle.

The reduction of the synthesis of void volume proteins, large glucagon immunoreactivity and proinsulin shows that the virus induced inhibition of protein synthesis affects alpha- and beta-cells, without specificity. Since EMC-virus causes encephalitis, myocarditis, inflammation of the exocrine pancreas and necrosis of the islets of Langerhans the inhibition of protein synthesis may also be found in other organs. This possibility was not examined.

In the islets from virus infected mice, the stimulation of proinsulin synthesis by glucose seems to be preserved until protein synthesis breaks down completely $72 \mathrm{hrs}$ after infection. It could not be established whether the incomplete inhibition of amino acid incorporation into proteins was due to incomplete infection of islet cells or to the maintenance of the cellular protein synthesis at a reduced level. It could not even be determined whether the infected beta-cell maintained its response to an increase of glucose concentration or whether the residual stimulation of proinsulin synthesis by glucose stems from non infected beta-cells.

Acknowledgements. This work was supported by the "Sandoz-Stiftung für therapeutische Forschung". - We thank Mrs. Heumann for skillful technical assistance.

\section{References}

1. Bablanian, R., Eggers, H. J., Tamm, J.: Studies on the mechanism of poliovirus-induced cell damage. Virology 26, 100-113 (1956)

2. Craighead, J. E., Steinke, J.: Diabetes mellitus-like syndrome in mice infected with EMC virus. Amer. J. Path. 63, 119-130 (1971)

3. Fromm, G. L. A., Craighead, J. E., McLain, M. F., Steinke, J.: Virus-induced diabetes in mice. Metabolism 17, 1154-1158 (1968)

4. Hahn, J., Steinhilber, S., Kerp, L.: An improved method of insulin determination in blood by the application of cellulose adsorption technique. Protides of the biological fluids Vol. 18 (ed. H. Peeters), pp. 465-468. Oxford-N.Y.: Pergamon Press 1971

5. Hellerström, C.: A method for the microdissection of intact pancreatic islets of mammals. Acta endocr. (Kbh.) 45, 122-132 (1964)

6. Kanich, J. E., Craighead, J. E., Kessler, J. B.: Lesions of renal glomeruli in mice with virus-induced diabetes mellitus-like disease. Diabetologia 9, 203-209 (1973)

7. Müntefering, H.: Zur Pathologie des Diabetes mellitus der weißen Maus bei der EMC-Virusinfektion. Virchows Arch. Abt. A. path. Anat. 356, 207-234 (1972) 
8. Noe, B. D., Bauer, G. E.: Evidence for glucagon biosynthesis involving a protein intermediate in islets of the anglerfish. Endocrinology 89, 642-651 (1972)

9. Panten, U., Dal Ri, H., Poser, W., Hasselblatt, A.: Eine Methode der Gewebsumströmung für Fluoreszenzmessungen. Pflïgers Arch. ges. Physiol, 323, 86-90 (1971)

10. Rigopoulou, D., Valverde, J., Marco, J., Faloona, G., Unger, R. H.: Large glucagon immunoreactivity in extracts of pancreas. J. biol. Chem. 245, 496-501 (1970)
11. Zimmermann, E., Heeter, M., Darnell, J. E.: RNA synthesis in poliovirus-infected cells. Virology 19, 400-408 (1963)

Prof. Dr. med. L. Kerp

Abt. f. klin. Endokrinologie

der Medizinischen Univ.-Klinik

78 Freiburg i. Br.

Hugstetterstr. 55

Federal Republic of Germany 